\title{
Waste Heat Recovery in Textile Industry: A Review
}

\author{
V.J.Sonawane, A.A.Keste \\ (Department of Mechanical Engineering, M.E.S. College of Engineering, Pune-01, Maharashtra, India.)
}

\begin{abstract}
Textile industry grows at fast rate to cater the need of ever increasing population. It is energy intensive industry. It is observed that heat loss in various processes is very large. Currently, developing countries are facing problem of shortage of energy. Due to globalization, it is necessary to be competitive by reducing energy consumption. There is huge scope to recover waste heat energy in textile industry. Heat recovery gives economic benefit to the industry. Heat recovery system requires less investment and payback period is small.
\end{abstract}

Keywords - Waste heat recovery, steam, boiler, condensate, economical, payback period.

\section{INTRODUCTION}

India ranks second in the textile industry sector in the world. The Indian textile industry contributes about $14 \%$ to the industrial production, $4 \%$ to the GDP, and $17 \%$ to the country's export earnings [1]. Steam is required in textile industry for different processes like dyeing, hot rinsing, etc. Hence, steam generation in boiler requires huge amount of fuel. Efficiency of boiler is 50 to $75 \%$. Hence it is possible to recover heat which otherwise get wasted in the atmosphere. Very high waste heat recovery potential exist in the textile industry. By optimizing the blow down rate of boiler it is possible to save huge amount of fuel per year. This improves profitability of industry by saving in fuel cost. By using condensate as feed water for boiler large saving in fuel can be achieved, as condensate contains $16 \%$ of energy as that of steam. When pressure reduces it is possible to recover heat from steam in the form of flash steam. It is possible to use waste water for heating feed water to the boiler, it also reduces fuel required for steam generation. This also meets the guidelines given by atmospheric norms. Waste heat recovery is also possible from hot exhaust air \& cooling water.

\section{THERMAL ENERGY USAGE IN TEXTILE INDUSTRY}

Thermal energy in textile mills is mainly consumed in two operations. They are heating of water and drying of water. The Table- 1 indicates the department wise per cent steam consumption in a composite textile mill. It can be observed maximum steam is consumed in processing department. All other department have comparable steam consumption. Power dominates consumption pattern in spinning/weaving, while thermal energy is major for chemical processing. It is known that thermal energy in textile mill is largely consumed in two operations, in heating of water and drying of water. Fuel consumption in textile mills is almost directly proportional to amount of water consumed. Hence, if consumption of water can be reduced, it will also save energy.

III. SOURCES OF WASTE HEAT RECOVERY IN TEXTILE INDUSTRY

Table 1 Percent Steam Consumption in a Composite Textile Mill

\begin{tabular}{|l|l|}
\hline Processing & $65 \%$ \\
\hline Sizing and size mixing & $15 \%$ \\
\hline Humidification in weaving and spinning & $10 \%$ \\
\hline $\begin{array}{l}\text { Unaccountable due to engineering, line } \\
\text { losses, leaks, etc. }\end{array}$ & $10 \%$ \\
\hline Total & $100 \%$ \\
\hline
\end{tabular}

Thermal energy in the form of steam is supplied to the various equipment's through pipe. The average steam consumption in unit operations and stages of wet processing are seen in the Table 2.

In textile industry, waste heat can be recovered from following sources:

1. Boiler blow down flash steam.

$5^{\text {th }}$ National Conference RDME 2016, 10-1 $1^{\text {th }}$ March 2016. 
2. Hot condensate flash steam.

3. Processed waste water which is dumped to sewage.

4. Exhaust hot air heat recovery.

5. Cooling water recovery

Table 2 The average steam consumption

\begin{tabular}{|l|l|}
\hline Dyeing Process & Steam consumption $\mathrm{kg} / \mathrm{kg}$ of fabric \\
\hline Dyeing in jigger in winches & 3.5 \\
\hline Dyeing in H.T.H.P. dyeing machine & 5 \\
\hline Pad-dry steam dyeing & 8 \\
\hline Pad - dry cure/thermosole dyeing & 5 \\
\hline
\end{tabular}

\section{BOILER BLOW DOWN RECOVERY}

As water evaporates in the boiler steam drum, solids present in the feed water are left behind. The suspended solids form sludge or sediments in the boiler, which degrades heat transfer. Dissolved solids promote foaming and carryover of boiler water into the steam. To reduce the levels of suspended and total dissolved solids (TDS) to acceptable limits, water is periodically discharged or blown down from the boiler. Mud or bottom blow down is usually a manual procedure done for a few seconds on intervals of several hours. It is designed to remove suspended solids that settle out of the boiler water and form a heavy sludge. Surface or skimming blow down is designed to remove the dissolved solids that concentrate near the liquid surface. Surface blow down is often a continuous process. Minimizing blow down rate can substantially reduce energy losses, as the temperature of the blown-down liquid is the same as that of the steam generated in the boiler. Minimizing blow down will also reduce makeup water and chemical treatment costs. Insufficient blow down may lead to carryover of boiler water into the steam, or the formation of deposits. Excessive blow down will waste energy, water, and chemicals. Minimizing blow down rate can substantially reduce energy losses, as the temperature of the blown-down liquid is the same as that of the steam generated in the boiler. Minimizing blow down will also reduce makeup water and

Chemical treatment costs. Boiler water is given a blow down in order to keep the accumulated. Total Dissolved Solids in boiler water in check as the steam is evaporated from the boiler. The quantity of blow down required is:

Blow down $(\mathrm{kg} / \mathrm{hr})=$.

$$
\frac{\text { Steam generation } \times \text { TDS in feed water }}{\text { TDS in boiler water }-T D S \text { in feed water }}
$$

Low Pressure FBC Boilers and Packaged Boilers are required to maintain a TDS of 3,500 ppm. A higher blow down than required will result in boiler water at steam temperature being drained resulting waste of energy in fuel. A lower blow down than required can result in carryover of boiler water into the boiler steam valve and steam distribution network. [3]

\subsection{Saving potential by optimizing blow down}

Report on Energy Audit at Creative Textile Mills Private Ltd, Vapi shows following saving potential: Presently blow down is given 2-3 times is every shift for one minute. The feed water TDS near to $60 \mathrm{ppm}$ and blow down TDS is maintained to $3500 \mathrm{ppm}$.

$$
\text { Blow down Quantity }=\frac{60 \times 6000}{(2500-60)}=148 \mathrm{~kg} / \mathrm{hr}
$$

For this boiler, you need to maintain 3500 TDS of blow down which will reduce blow down quantity and thus heat input to boiler.

$$
\text { Proposed blow down }=\frac{60 \times 6000}{(3500-60)}=104 \mathrm{~kg} / \mathrm{hr}
$$

Heat Saving $=44 \times 620 \mathrm{Kcal} / \mathrm{hr}=27280 \mathrm{Kcal} / \mathrm{hr}$

$5^{\text {th }}$ National Conference RDME 2016, 10-1 $1^{\text {th }}$ March 2016. 


\author{
Equivalent fuel saving $=4.7 \mathrm{~kg} / \mathrm{hr}$ \\ Saving potential@Rs.4.5/kg fuel =Rs.170000/year [2]
}

\title{
V. CONDENSATE HEAT RECOVERY
}

Steam contains two types of energy: latent and sensible. When steam is supplied to a process application (heat exchanger, coil, etc.) the steam vapor releases the latent energy to the process fluid and condenses to a liquid condensate. The condensate retains the sensible energy the steam had. The condensate can have as much as $16 \%$ of the total energy in the steam vapor, depending on the pressure[2].It is beneficial to return condensate to boiler. It reduces fuel consumption as condensate is hot. Requirement of makeup water is also reduced. Condensate has high purity which if recovered can reduce energy losses due to boiler blow down. The polyester production process analysis showed that condensate returning from the reactor to the steam boiler raises inlet temperature, giving a reduced fuel requirement of about $8 \%$ [6]. Flash steam recovery Condensate is discharged through traps from a higher to a lower pressure. As a result of this drop in pressure, some of the condensate will then re-evaporate into 'flash steam. The flash steam generated can contain up to half of the total energy of the condensate, hence flash steam recovery is an essential part of an energy efficient system [2].

$$
\% \text { Flash Steam }=\frac{(S H-S L)}{H} \times 100
$$

Where $\mathrm{SH}=$ Sensible heat in the condensate at the higher pressure before discharge

$\mathrm{SL}=$ Sensible heat in the condensate at the lower pressure to which discharge takes place and

$\mathrm{H}=$ Latent heat in the steam at the lower pressure to which the condensate has been discharged.

Saving potential in flash steam recovery

Report on Energy Audit at Creative Textile Mills Private Ltd, Vapi shows following saving potential:

Flash steam from blow down @ 7 bar $(g)=8 \mathrm{~kg} / \mathrm{hr}$

Heat in flash steam $=8 \times 640=5120 \mathrm{Kcal} / \mathrm{hr}$

Heat in blow down water $=11520 \mathrm{Kcal} / \mathrm{hr}$

Total Heat available $=16640 \mathrm{Kcal} / \mathrm{hr}$

Increase if $F . W$ temperature $=2.8^{\circ} \mathrm{C}$

Equivalent fuel saving $=2.8 \mathrm{~kg} / \mathrm{hr}$

Saving potential@Rs.4.5/kgfuel =Rs.102000/year

\section{WASTE WATER HEAT RECOVERY}

Waste water contains heat which can be utilized in heating process water. As per environmental norms, waste water cannot be disposed at high temperature. So, it becomes important to recover the heat .It is common practice now to recover heat from hot waste water $\left(>60^{\circ} \mathrm{C}\right)$ to preheat fresh cold water $\left(25^{\circ} \mathrm{C}\right)$ to meet the demand of up to $40 \%$ of hot fresh water for wet processing of textiles with a reduction in fuel consumption by $15-20 \%$. Energy calculation of wastewater discharged from a wet processing textile unit producing 10 tons of textiles per day and using heavy fuel oil, shows that annual energy savings of up to $\$ 120,000$ may be made through hot wastewater alone [8]. Shell-and-tube and plate heat exchangers have been used with mixed results in heat recovery in industry (Finbeiner, 1987; Raymand 1984; APV, 1996). The latter is generally preferred to the former because its heat transfer efficiency is higher by 3 to5 times. Plate heat exchangers require less capital investment than shell-and-tube heat exchangers made of materials like high-grade stainless steel, essential to resist corrosion due to textile waste water [4].

\section{HEAT RECOVERY FROM AIR}

Drying is one of the most energy-intensive operations in textile processes and dryers exhaust large amounts of warm and moist air into environment. An analysis was carried out on heat-recovery systems which utilize the heat produced in the drying process. A heat recovery system was designed and employed on the convection-type drying machine and significant energy savings were achieved [6].The temperature of hot exhaust air from dryers may reach up to $140-180^{\circ} \mathrm{C}$ and the heat energy recovery potential is great. It has been found that, in an air-towater heat recovery system, fresh water (at $60^{\circ} \mathrm{C}$ and a flow rate of $12 \mathrm{~m} / \mathrm{h}$ ) may be heated to over $70^{\circ} \mathrm{C}$ using 
hot exhaust air (at $140^{\circ} \mathrm{C}$ and a flow rate of $10,000 \mathrm{~m}^{3} / \mathrm{h}$ ). This may represent an energy conservation of up to $10 \mathrm{~T}$ of heavy oil per year [8].

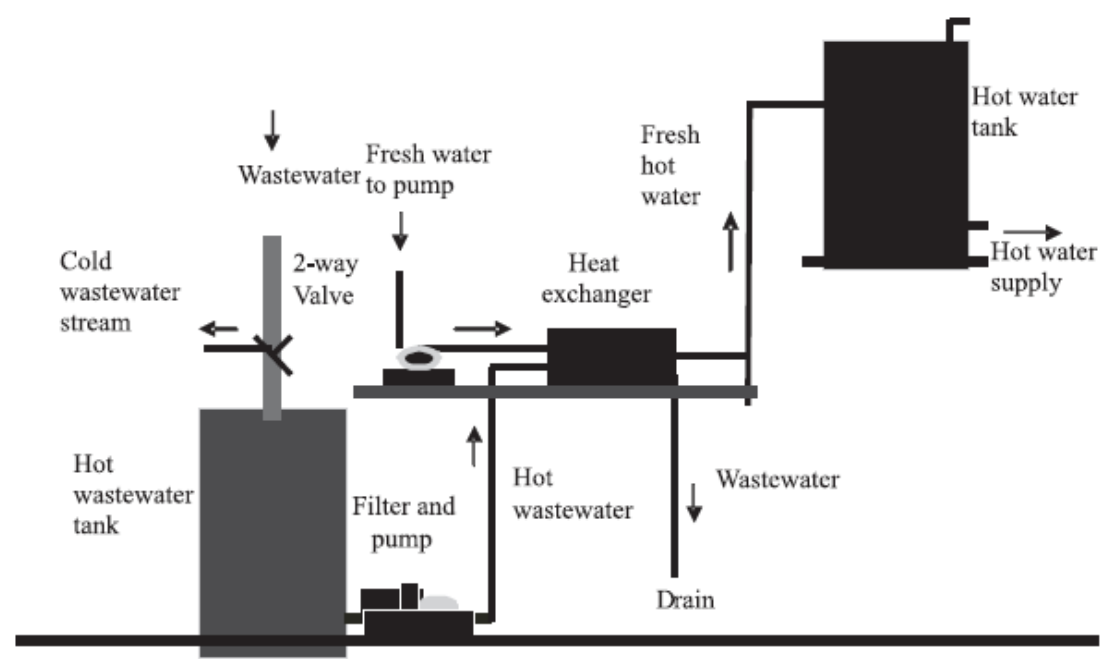

Figure 1: Centralised waste water heat recovery

VIII. COOLING WATER RECOVERY

Cooling of baths is a common operation. The utilisation of cooling water, that is, of a stream of cold water to absorb heat from the hot bath, can also be considered as a heat recovery process. Subsequently, cooling water is collected and re-utilised, thus, recovering heat and water. Under the most favourable conditions, cooling water recovery has been reported to have a payback period of 12 months [4].

\section{CASE STUDY FROM ECONOMIC POINT OF VIEW}

9.1 Textile industry in Bursa (Turkey)

Case study of textile industry implementing Waste Heat Recovery System in Bursa city in Turkey shows following observations [7]: Process values which are presented in Table 3 are the average values of seven different dyeing plants over 205 active dyeing plants in Bursa. Economical evaluation and second law analysis are carried out for one of the plant that has eight dyeing units. The investigated process consists of eight steps of which are bleaching, washing, acidification, dyeing, cold rinsing, washing, hot rinsing and finishing

Table-3Average values of parameters

\begin{tabular}{|l|l|l|l|}
\hline Process & $\begin{array}{l}\text { Process } \\
\text { time } \\
(\mathrm{min})\end{array}$ & $\begin{array}{l}\text { Temperature } \\
\left({ }^{\circ} \mathrm{C}\right)\end{array}$ & $\begin{array}{l}\text { Volume } \\
(\text { Ltrs })\end{array}$ \\
\hline 1.Bleaching & 30 & 96 & 5000 \\
\hline 2.Washing & 20 & 96 & 5000 \\
\hline 3.Acidification & 10 & 50 & 5000 \\
\hline 4.Dyeing & 60 & 96 & 5000 \\
\hline 5.Cold rinsing & 10 & 30 & 5000 \\
\hline 6.Washing & 20 & 90 & 5000 \\
\hline 7.Hot rinsing & 10 & 70 & 5000 \\
\hline 8.Finishing & 20 & 40 & 5000 \\
\hline
\end{tabular}

Governing parameters that are used for calculation of WHRS are mass flow rate, temperature and process time, respectively. Results of the used computer code for the case study and schematic illustration of the WHRS can be seen in Fig.2. Heat exchanger, the main unit of WHRS, is especially investigated [7]. 
Table-4 Results of the thermodynamic analysis

(One shell—four passes heat exchanger)

\begin{tabular}{|l|l|l|}
\hline Parameter & Quantity & Unit \\
\hline Heat transfer capacity, Q & 2020 & $\mathrm{~kW}$ \\
\hline Heat transfer surface area, As & 228.4 & $\mathrm{~m}^{2}$ \\
\hline Effectiveness & 0.92 & - \\
\hline Exergy destruction rate & 76.35 & $\mathrm{~kW}$ \\
\hline Entropy generation rate & 0.265 & $\mathrm{~kW} / \mathrm{K}$ \\
\hline Second law efficiency & 0.667 & - \\
\hline Total cost of the WHRS & 110773 & $\$$ \\
\hline Annual economical profit, EP & 423837 & $\$ /$ year \\
\hline
\end{tabular}

The following several assumptions are adopted for the first and second law analyses and economical evaluation.

1. All processes are steady state and steady flow with negligible potential and kinetic energy effects and no chemical reaction.

2. The direction of heat transfer to the system is positive.

3. The dead state conditions are taken as $\mathrm{T}_{\mathrm{o}}=15^{\circ} \mathrm{C}$ and $\mathrm{P}_{\mathrm{o}}=100 \mathrm{kPa}$.

4. Cold rinsing and finishing steps are neglected because the processes has relatively low temperature. So, the wastewater volumetric flow rate is 30,000 Ltrs/one pass consignment.

5. One dyeing process is carried out in one shift of the plant Dyeing plant has eight units and three shifts a day. The total volumetric flow rate of waste water is: $3 \times 8 \times 30,000=720,000 \mathrm{~L} /$ day $=720$ tonne/day.

6. Dyeing plant working period is accepted as $24 \mathrm{hr} /$ day and 300 day/year.

7. The cooling water inlet temperature, $\left(\mathrm{T}_{\mathrm{cw}}\right)_{\mathrm{in}}$, is $20^{\circ} \mathrm{C}$ and the cooling water outlet temperature, $\left(\mathrm{T}_{\mathrm{cw}}\right)_{\mathrm{out}}$, is 60 ${ }^{\circ} \mathrm{C}$ for the needs of textile finishing processes.

Different dyeing steps have different process temperature values. Average inlet temperature of the waste water discharged from dyeing plant can be calculated as;

$$
T_{n w_{d} i n}=\frac{\sum_{i=1}^{n} \dot{m}_{\mathrm{i}} C_{p_{\mathrm{i}}} T_{\mathrm{i}}}{\sum_{\mathrm{i}=1}^{n} m_{\mathrm{i}} C_{p_{\mathrm{i}}}}
$$

Economical profit (EP) of the WHRS can also be expressed as the price of the equivalent natural-gas rate to the Recovered heat transfer. Economical profit is calculated based on the rate of recovered heat transfer. Natural-gas price (NGP) is taken as $0.2512 \$ / \mathrm{m}^{3}$.

$$
E P=\text { (Mass flow rate of natural gas) } \times \text { NGP }
$$

Taal et al [10]. compared different methods of cost estimation for heat exchangers. Cost of cross-flow and multipass shell and tube type heat exchanger with multiple passes of the tube bundles for stainless steel material can be calculated from following Eq.

$$
\text { Cost of Heat Exchanger }=10000+324 A_{g}^{0,91}
$$

Stainless steel is selected as the heat exchanger material because of the corrosive properties of used waste water. Total cost of the investment is sum of the heat exchanger, installation and auxiliary equipment costs. Cost of pumps, valves, pipes, re-organization of installation area, connections, tests and regulations, transportation, engineering service costs should be taken into consideration for a feasible system. The other costs mentioned above are nearly doubled the cost of heat exchanger alone.

Net cash flows and net benefits are important for the Project developers. Net present value, NPV, method is a powerful indicator of the viability of the projects and can be determined from the following equation:

$$
N P V=\sum_{\mathrm{i}=1}^{n}(B-C)_{\mathrm{i}} a_{\mathrm{i}}
$$


Where, NPV is the net present value, $\mathrm{B}$ is the benefit, $\mathrm{C}$ is the

Cost and " $a$ " is the discount rate. Discount rate, a, can be calculated as

$$
a=\frac{1}{(1+i)^{p}}
$$

Where $\mathrm{i}$ is the interest rate and $\mathrm{p}$ is the period of month. Tables 3and 4are shown the results of the technical and economic analysis of the case study, respectively. It is clearly observed from Tables 3 and 4 that the NPV is reached positive value in 4 months i.e. payback period, PBP, is about 4 months and therefore the investment seems to be very feasible. According to data of Bursa Chamber of Commerce and Industry, there are 205 active dyeing plants in Bursa. So, the total economic value of waste-heat is easily calculated as approximately $87,000,000$ \$/year in Bursa [7].

9.2 Surat Textile cluster

Economic benefit after implementing Waste Heat Recovery System (WHRS) for drained water in Surat textile cluster is shown in Table 5 [9].

Table 5 Waste Heat Recovery System (WHRS) for drained water in Surat textile cluster

\begin{tabular}{|c|l|l|l|}
\hline Sr. No. & Particulars & Unit & Value \\
\hline 1 & $\begin{array}{l}\text { Quantity of drained } \\
\text { water }\end{array}$ & Ltrs/day & 62000 \\
\hline 2 & $\begin{array}{l}\text { Average quantity per } \\
\text { day }\end{array}$ & Ltrs/day & 49600 \\
\hline 3 & $\begin{array}{l}\text { Temperature of hot } \\
\text { drain water }\end{array}$ & ${ }^{\circ} \mathrm{C}$ & 90 \\
\hline 4 & $\begin{array}{l}\text { Temperature of hot } \\
\text { drain water after WHR }\end{array}$ & $\mathrm{C}$ & 50 \\
\hline 5 & $\begin{array}{l}\text { Quantity of heat can be } \\
\text { recovered }\end{array}$ & $\mathrm{kCal} /$ day & 1984000 \\
\hline 6 & $\begin{array}{l}\text { Present } \\
\text { efficiency }\end{array}$ & $\%$ & 65 \\
\hline 7 & Calorific value of fuel & $\mathrm{kCal} / \mathrm{kg}$ & 6000 \\
\hline 8 & Fuel saving per annum & Tonne/annum & 178.1 \\
\hline 9 & Cost of fuel & Rs./tonne & 3800 \\
\hline 10 & Saving in rupees & Rs./year & $7,66,000$ \\
\hline
\end{tabular}

\section{CONCLUSION}

Apart from saving energy, we can achieve sustainable development with waste heat recovery as dependence on fossil fuels is reduced. Performance of thermal systems is enhanced in addition with reduction in pollution. From the case studies it has been estimated that payback period of investment for the waste heat recovery system is in between one to two years for most of the systems. Hence waste heat recovery is highly economical.

\section{REFERENCES}

[1] Ministry of Power, India, "BEE PAT booklet", 2012, 1-9.

[2] K.M. Sherin, M G Prince, "Potential of Waste HeatRecovery in Textile Industries", Int. Journal of Engineering Research and Applications, 3(5), (2013), .324-328.

[3] P. F. Gorimar, "Report on Energy Audit at Creative Textile Mills Private Ltd. Vapi", Date of Audit : 8-17 September,2009.

[4] K.l Elahee, " Heat recovery in the textile dyeing and finishing industry:lessons from Developing economies", Journal of Energy inSouthern Africa , 21(3), 2010.

[5] S. Sharma "Energy Management in Textile Industry", International Journal of Power System Operation and Energy Management, 2(1,2), 45-49. 
[6] U. Kumar and M.N. Karimi “ Low grade Waste Heat Recovery for Optimized Energy Efficiencies and Enhanced Sustainability in Process Industries: A Comprehensive Review”, International Journal ofMultidisciplinaryScience and Engineering, 5(4), 2014.

[7] E. Pulat, A.B. Etemoglu, M. Can ,"Waste-heat recovery potential in Turkish textile industry: Case study for city of Bursa", Renewableand Sustainable Energy Reviews 13, (2009), 663-672.

[8] C. Bhurtun, N. Kistamah and J. Chummun ,"Energy Saving Strategy In Textile Industry: The Case of Mauritius".

[9] Bureau of Energy Efficiency;“Detailed Project Report on Waste Heat Recovery System”, Textile SME Cluster, Surat, Gujarat (India),New Delhi;Detail Project Report No.: SRT/TXT/WHR/15,Year-2010.

[10] M.1 Taal, I Bulatov, J. Klemeš, P. Stehlík, J. KLEMEŠ, “Cost estimation and energy price forecasts for economic evaluation of retrofit projects', 23 (14),1819-1835.

\section{WASTE HEAT RECOVERY}

\begin{tabular}{|c|}
\hline Unit 1 \\
\hline Unit 2 \\
\hline Unit 3 \\
\hline Unit 4 \\
\hline Unit 5 \\
\hline Unit 6 \\
\hline Unit 7 \\
\hline Unit 8 \\
\hline
\end{tabular}

Waste water inlet $m_{\text {ww }}=720000[\mathrm{~kg} / \mathrm{day}] \dot{\mathrm{m}}_{\text {wev, }}=8.333[\mathrm{~kg} / \mathrm{s}$

Fuel mass flowrate

$m_{y . y}=1687272.73$ [m3/year]

$m_{y, g}=5624[\mathrm{~m} 3 / \mathrm{day}]$

$m_{y}=234.3[\mathrm{~m} 3 / \mathrm{h}]$

Capacity $Q_{h e}=2020[\mathrm{KW}]$

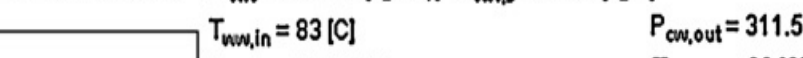

$T_{\text {cw, out }}=60[C]$

Cooling water outlet

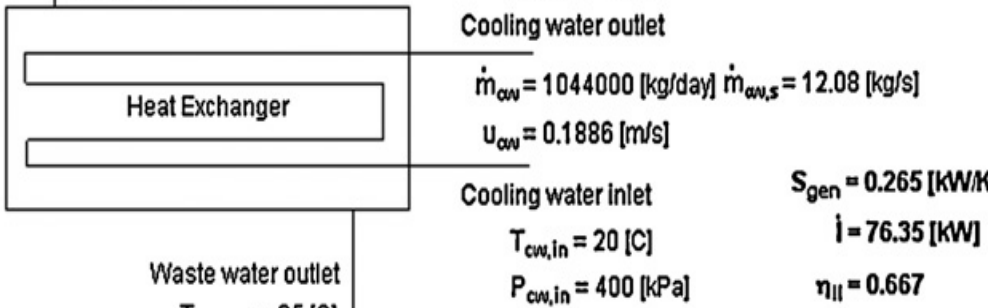

$T_{\text {wnv,out }}=25[\mathrm{C}]$

$P_{\text {ww,out }}=100[\mathrm{kPa}]$

$d_{d}=25[\mathrm{~mm}]$

$d_{i}=21[\mathrm{~mm}]$

$\mathrm{TP}=4$ [pass]

$n=185$ [tube per pass]

As $=228.4[\mathrm{~m} 2]$
Naturalgas equilavent profit

$\mathrm{NEP}_{y}=423837$ [USD/year]

$\mathrm{NEP}_{9}=1413$ [USD/day]

$\mathrm{NEP}=58.87[\mathrm{USD} / \mathrm{h}]$

NEP $_{\text {total }}=86886585$ [USD/year]

$T C=110773[U S D]$

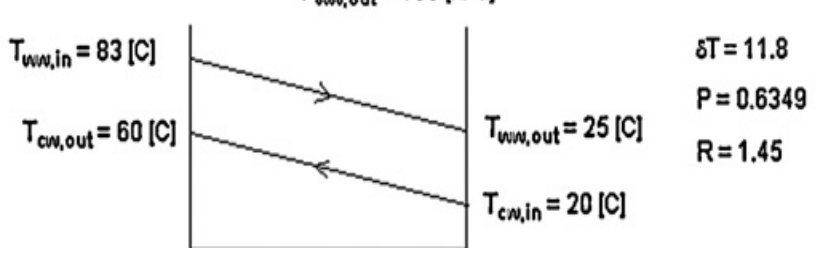

Fig.2 Schematic illustration of WHRS [6]. 